\title{
PETA KENDALI EXPONENTIALLY WEIGHTED MOVING AVERAGE (EWMA) UNTUK JUMLAH WISATAWAN YANG BERKUNJUNG KE SUMATERA BARAT
}

\author{
NELWATI, HAZMIRA YOZZA, MAIYASTRI \\ Program Studi Matematika, \\ Fakultas Matematika dan Ilmu Pengetahuan Alam, Universitas Andalas, \\ Kampus UNAND Limau Manis Padang, Indonesia, \\ nelwati1905@gmail.com
}

\begin{abstract}
Abstrak. Pola jumlah wisatawan yang berkunjung ke Sumatera Barat harus selalu dipantau dan dikendalikan oleh pemerintah daerah tersebut. Dalam statistika dikenal suatu metode untuk melihat keterkendalian jumlah wisatawan yang berkunjung ke Sumatera Barat yang dinamakan pengendalian mutu statistik. Dalam penelitian ini akan digunakan salah satu alat dalam SPC yaitu peta kendali Exponentially Weighted Moving Average (EWMA). Peta Kendali ini dapat digunakan untuk melakukan pengendalian statistik terhadap jumlah kunjungan wisatawan ke Sumatera Barat yang merupakan data deret waktu. Pada penelitian ini peta kendali EWMA dibentuk dari jumlah kunjungan wisatawan yang berasal dari negara Malaysia, Australia, Singapura, negara-negara Eropa, Amerika, dan negara lainnya. Peta kendali EWMA negara-negara ini memiliki pola yang hampir sama dan seluruh nilai EWMA berada dalam batas kendali kecuali negara Singapura. Negara Malaysia memiliki nilai EWMA yang paling besar dibandingkan negara-negara lainnya, yang berarti jumlah kunjungan wisatawan asal Malaysia lebih tinggi dibandingkan negara lainnya.
\end{abstract}

Kata Kunci: SPC, Peta Kendali EWMA, Data Pariwisata dan Transportasi Sumatera Barat

\section{Pendahuluan}

Wisata adalah bepergian secara bersama-sama dengan tujuan untuk bersenangsenang, menambah pengetahuan, dan lain-lain. Pariwisata adalah segala macam kegiatan wisata yang dilayani oleh pemerintah, masyarakat, atau pengusaha beserta fasilitasnya. Pada tahun 2013, sektor pariwisata di Indonesia menyumbangkan produk domestik bruto sebesar Rp. 347 triliun. Angka itu mencapai 23 persen dari total pendapatan negara yang tercantum di Anggaran Pendapatan dan Belanja Negara perubahan 2013.

Banyak faktor yang menjadi daya tarik wisatawan untuk berkunjung ke suatu daerah. Sumatera Barat adalah salah satu daerah tujuan wisata di Indonesia. Sumatera Barat memiliki hampir semua objek wisata alam yang terkenal indah seperti laut, pantai, danau, gunung, dan ngarai. Budaya Minangkabau yang unik juga menjadi daya tarik bagi wisatawan untuk berkunjung ke Sumatera Barat. Diadakanya beberapa event internasional juga menjadi daya tarik wisatawan berkun- 
jung ke Sumatera Barat, seperti Tour de Singkarak (TDS), Sawahlunto International Music Festival (SIMFes), Sawahlunto International Songket Carnival, dan masih banyak yang lainnya. Perkembangan pariwisata suatu tempat seringkali dihubungkan dengan jumlah wisatawan yang berkunjung ke suatu tempat pariwisata. Indikator ini menjadi salah satu tolok ukur perkembangan pariwisata di daerah tersebut. Perkembangan jumlah wisatawan yang berkunjung ke Sumatera Barat ini, dapat dilihat pola kenaikan dan penurunannya dari waktu ke waktu. Pola kunjungan wisatawan tersebut harus senantiasa dipantau dan dikendalikan oleh pemerintah suatu daerah tersebut. Dalam statistika, pengendalian kualitas suatu atribut dapat dilakukan dengan metode pengendalian mutu statistik. Pengendalian mutu statistik merupakan teknik penyelesaian masalah yang digunakan untuk memonitor, mengendalikan, menganalisis, mengelola, dan memperbaiki produk dan proses menggunakan metode-metode statistik. Salah satu alat pengendalian mutu statistik tersebut yakni peta kendali, diantaranya dikenal suatu peta kendali untuk data deret waktu dengan pergeseran mean (rata-rata) yang kecil yaitu peta kendali $E x$ ponentially Weighted Moving Average (EWMA). Penelitian ini bertujuan untuk menyajikan dan mendeskripsikan peta Kendali EWMA untuk jumlah kunjungan wisatawan ke Sumatera Barat yang merupakan data deret waktu.

\section{Statistical Process Control (SPC)}

Statistical Process Control, yang disingkat dengan SPC atau dalam Bahasa Indonesia dikenal dengan Statistika Pengendali Proses (SPP) adalah suatu terminologi yang digunakan untuk menjabarkan penggunaan teknik-teknik dalam memantau dan meningkatkan performansi untuk menghasilkan produk yang berkualitas. Pada dasarnya Statistical Process Control merupakan penggunaan metode statistik untuk mengumpulkan dan menganalisa data dalam menentukan dan mengawasi kualitas. Dalam SPC, ada beberapa alat yang dapat digunakan seperti check sheet, diagram pareto, flowchart, diagram sebab-akibat, histogram, peta kendali, dan diagram pencar.

\section{Peta Kendali Exponentially Weighted Moving Average (EWMA)}

Peta kendali Exponentially Weighted Moving Average atau dapat disingkat EWMA diperkenalkan pertama kali oleh S.W Roberts pada tahun 1959 dan digunakan untuk memonitor proses dan mendeteksi adanya sebab-sebab terusut/sebab khusus yang terlihat dari adanya pergeseran terus menerus dalam suatu proses. Peta kendali EWMA ini terutama digunakan untuk mendeteksi adanya pergeseran nilai mean/rata-rata yang kecil dalam suatu proses. Peta kendali EWMA secara luas digunakan untuk peramalan data Time Series.

Peta kendali EWMA ini secara efektif dapat dibuat untuk ukuran subgrup yang kecil. Misalkan $x_{i}$ adalah data deret waktu dan $\lambda$ menjadi faktor pembobot yang nilainya antara 0 dan 1. Nilai Exponentially Weighted Moving Average (EWMA) didefinisikan sebagai:

$$
z_{i}=\lambda x_{i}+(1-\lambda) z_{i-1}
$$


untuk $i=1,2, \cdots, m$ dan $0<\lambda \leq 1$ adalah konstan. Nilai $z_{0}$ merupakan nilai awal yang diperlukan untuk mendapatkan nilai EWMA pada sampel pertama $(i=1)$.

Nilai ini dapat berasal dari penetapan sebelumnya oleh produsen sebagai nilai target, $z_{0}=\mu_{0}$ atau dapat berasal dari perhitungan berikut,

$$
z_{0}=\overline{\bar{x}}=\left(\frac{\sum_{j=1}^{m} \bar{x}_{j}}{m}\right),
$$

dengan $\bar{x}_{j}=\frac{\sum_{i=1}^{n} x_{i j}}{n}$, dimana $n:$ ukuran subgrup dan $m:$ banyak subgrup. Jika pengamatan $x_{i}$ adalah variabel acak independen (bebas), untuk $i=1,2, \cdots, m$ dengan ragam $\sigma^{2}$, maka ragam dari $z_{i}$ adalah :

$$
\sigma_{z_{i}}^{2}=\sigma^{2}\left(\frac{\lambda}{(2-\lambda)}\right)\left[1-(1-\lambda)^{2 i}\right], \text { untuk } i=1,2, \cdots, m
$$

Peta kendali EWMA dibangun dengan memplotkan $z_{i}$, untuk $i=1,2, \cdots, m$ terhadap subgrup (atau waktu). Garis tengah EWMA adalah sebagai berikut :

Garis tengah $=\mu_{0}$

Nilai $\mu_{0}$ diduga dengan nilai $\overline{\bar{x}}$. Batas kendali peta kendali EWMA untuk masingmasing waktu adalah sebagai berikut:

$$
\begin{aligned}
& U C L_{i}=\mu_{0}+L \sigma \sqrt{\left(\frac{\lambda}{(2-\lambda)}\right)\left[1-(1-\lambda)^{2 i}\right]}, \text { untuk } i=1,2, \cdots, m \\
& L C L_{i}=, \mu_{0}-L \sigma \sqrt{\left(\frac{\lambda}{(2-\lambda)}\right)\left[1-(1-\lambda)^{2 i}\right]}, \text { untuk } i=1,2, \cdots, m
\end{aligned}
$$

Nilai $\sigma$ diduga dengan $s_{x_{i}}^{2}=\frac{\sum_{j=1}^{n} x_{i j}^{2}-\left(\sum_{j=1}^{n} x_{i j}\right)^{2}}{n-1}$, untuk $i=1,2, \cdots, m$, dimana :

$$
\begin{aligned}
U C L_{i} & =\text { batas kendali atas untuk subgrup ke } i . \\
L C L_{i} & =\text { batas kendali Bawah untuk subgrup ke } i . \\
\lambda & =\text { faktor pembobot dari EWMA. } \\
\sigma & =\text { standar deviasi masing-masing subgrup. } \\
L & =\text { lebar batas kendali peta kendali EWMA. }
\end{aligned}
$$

Dalam Persamaan 3.3 dan 3.4, faktor $L$ adalah lebar batas kendali. Secara umum nilai-nilai $\lambda$ yang sering digunakan adalah $0,05 \leq \lambda \leq 0,25$ yang dapat bekerja dengan baik, namun yang paling sering digunakan adalah nilai $\lambda=0,1$ dan 0,2 . Jika nilai $\lambda$ makin kecil maka nilai $z_{i}$ semakin besar. Berarti untuk nilai $\lambda$ yang semakin kecil peta kendali EWMA lebih efektif dalam mendeteksi pergeseran nilai mean yang kecil. Jadi nilai faktor pembobot $\lambda$ berpengaruh terhadap kepekaan peta kendali EWMA dalam mendeteksi pergeseran nilai mean yang kecil. Dan nilai $L=3$ (biasa batas tiga sigma) bekerja cukup baik. 


\section{Metodologi Penelitian}

Data yang digunakan adalah data pariwisata dan transportasi Sumatera Barat tentang jumlah wisatawan dari negara Malaysia, Australia, Singapura, negara-negara Eropa, Amerika, dan negara-negara lainnya yang berkunjung ke Sumatera Barat pada bulan Januari 2013 sampai bulan Desember 2014.

Langkah-langkah dalam membuat peta kendali EWMA yaitu:

(1) Cari nilai rata-rata $\overline{\bar{x}}$ dan $s^{2}$ untuk setiap negara.

(2) Hitung nilai $z_{i}=\lambda x_{i}+(1-\lambda) z_{i-1}$, dimana $z_{0}=\mu_{0}=\overline{\bar{x}}$.

(3) Hitung UCL, LCL dan CL $(\overline{\bar{x}})$ dengan persamaan

(a) $C L=\overline{\bar{x}}=\frac{\sum_{i=1}^{m} \bar{x}_{i}}{m}$, dimana CL $($ center line $)=$ nilai tengah.

(b) $U C L_{i}=\mu_{0}+L \sigma \sqrt{\left(\frac{\lambda}{2-\lambda}\right)\left[1-(1-\lambda)^{2 i}\right]}$, dan

(c) $L C L_{i}=\mu_{0}-L \sigma \sqrt{\left(\frac{\lambda}{2-\lambda}\right)\left[1-(1-\lambda)^{2 i}\right]}$.

(4) Plot no subgrup terhadap nilai EWMA $\left(z_{i}\right)$, nilai CL, nilai UCL, dan nilai LCL, kemudian hubungkan nilai $z_{i}$, nilai CL, nilai UCL, dan nilai LCL terhadap subgrup.

(5) Interpretasikan peta kendali EWMA yang terbentuk.

\section{Pembahasan}

Tahap awal dalam membuat peta kendali EWMA adalah menentukan nilai $z_{i}$, UCL dan LCL. Pada penelitian ini akan digunakan $\lambda=0,2$ dan $L=3$, selanjutnya akan dicari nilai EWMA, UCL dan LCL dari masing-masing negara.

\subsection{Peta Kendali EWMA untuk Negara Malaysia}

Negara Malaysia adalah negara yang sangat dekat dan sangat erat hubungannya dengan Indonesia, sehingga tingkat kunjungan warga negara Malaysia ke Indonesia cukup tinggi, terutama ke Sumatera Barat. Untuk melihat bagaimana perkembangan jumlah wisatawan yang datang berkunjung setiap bulannnya ke Sumatera Barat, maka dibuat peta kendali Exponentially Weighted Moving Average (EWMA) berikut.

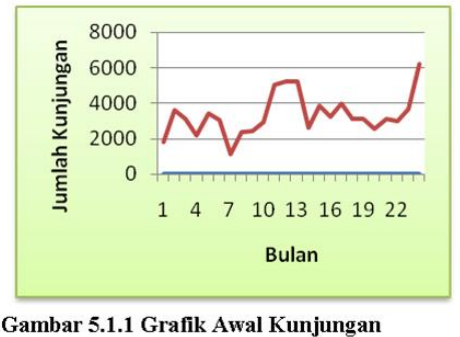
Gambar 5.1.1 Grafik Awal Kunjungan
Wisatawan Asal Malaysia

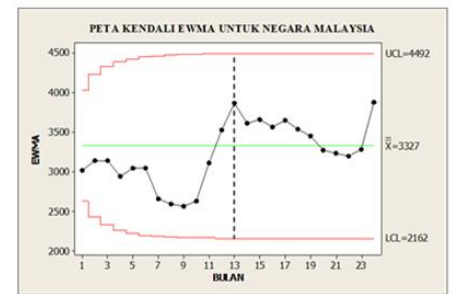

Gambar 5.1.2 Peta Kendali EWMA Negara 
Dari peta kendali EWMA negara Malaysia di atas terlihat bahwa seluruh data berada dalam batas kendali, tetapi memiliki pola yang tidak acak. Garis putusputus pada peta kendali EWMA memisahkan peta kendali EWMA untuk tahun 2013 dengan tahun 2014. Terlihat bahwa pola kedua tahun tersebut adalah sama. Pada bulan Januari sampai bulan Juni data cenderung konstan, tetapi dari bulan Juni data mengalami penurunan dan titik terendahnya pada bulan September. Kemudian terjadi kenaikan kembali sampai pada puncaknya yakni bulan Desember. Pola ini menjadi informasi pola kunjungan wisatawan dari Malaysia ke Sumatera Barat, yakni jumlah kunjungan tertinggi terjadi pada bulan Desember dan kunjungan terendah terjadi pada bulan September.

\subsection{Peta Kendali EWMA untuk Negara Australia}

Negara Australia adalah tetangga negara Indonesia yang terdekat, terlihat dari peta dunia yang mana letak negara Australia ini sangat dekat dengan negara Indonesia, sehingga banyak warga negara Australia yang datang berkunjung ke Indonesia termasuk ke Sumatera Barat. Salah satu daerah di Sumatera Barat yang sering dikunjungi wisatawan asal Australia ini adalah Mentawai. Hal ini disebabkan wisatawan asal Australia yang mencari tempat berselancar yang bagus dengan ombak yang besar. Pola kunjungan wisatawan asal Australia ke Sumatera Barat dan peta kendali EWMA sebagai berikut.

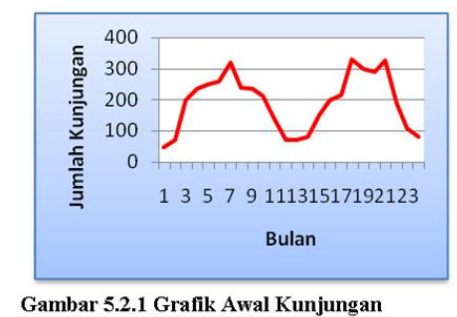

Gambar 5.2.1 Grafik Awal Kunjungan
Wisatawan Asal Australia

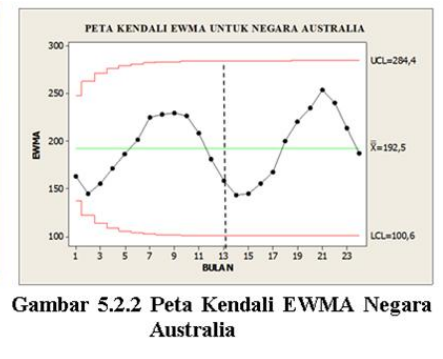

Dari peta kendali EWMA di atas terlihat bahwa pola sudah mengalami pemulusan, sehingga titik-titik yang ekstrim (variasi data) pada data awal dapat dihilangkan. Seluruh data berada dalam batas kendali, tetapi memiliki pola yang tidak acak. Dari bulan Januari ke bulan Februari data mengalami sedikit penurunan, tetapi dari bulan Februari data mengalami pola naik sampai pucaknya pada bulan September kemudian mengalami penurunan kembali sampai bulan Desember. Titik terendah terjadi pada bulan Februari yang berarti jumlah kunjungan wisatawan dari Australia paling sedikit pada bulan tersebut. Puncak tertinggi terjadi pada bulan September yang berarti jumlah kunjungan wisatawan dari Australia meningkat pada bulan September.

\subsection{Peta Kendali EWMA untuk Negara Singapura}

Negara Singapura adalah negara yang menjalin hubungan bilateral dengan negara Indonesia dan merupakan sama-sama negara ASEAN, yang memungkinkan 
banyaknya warga negara Singapura yang datang berkunjung ke Sumatera Barat. Peta Kendali EWMA untuk wisatawan asal Singapura adalah sebagai berikut.

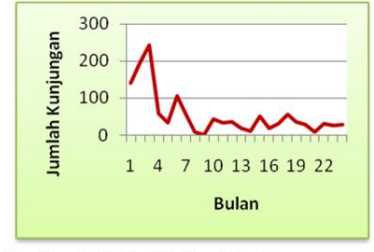

Gambar 5.3.1 Grafik Awal Kunjungan Wisatawan Asal Singapura

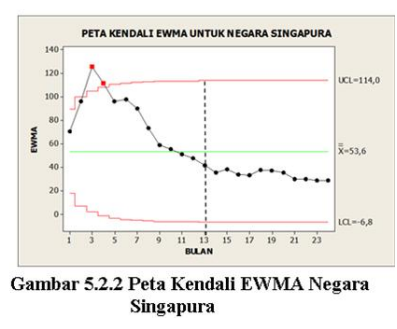

Singapura

Dari peta kendali EWMA di atas terlihat bahwa terdapat data yang berada di luar batas kendali dan memiliki pola yang tidak acak. Peta kendali EWMA tahun 2013 dan tahun 2014 dipisahkan dengan garis putus-putus untuk melihat perbandingan pola kedua tahun tersebut. Dapat dilihat bahwa peta kendali EWMA untuk negara Singapura ini mengalami pola yang cenderung terus turun setiap bulannya, dan hanya pada bulan ke-3 (Maret) dan ke-4 (April) tahun 2013 polanya menaik cukup tinggi bahkan melewati batas kendali atasnya. Pola yang dimiliki peta kendali EWMA negara Singapura ini berbeda dengan negara lainnya yang memiliki pola yang hampir sama dikedua tahun tersebut. Peneliti tidak mendapatkan informasi tentang penyebab terjadinya kenaikan yang cukup tinggi pada jumlah kunjungan bulan Maret dan April 2013 tersebut.

\subsection{Peta Kendali EWMA untuk Negara-negara Eropa}

Negara-negara Eropa yang berkunjung ke Sumatera Barat tersebut terdiri dari negara Inggris, Perancis, Belanda dan Jerman yang merupakan negara-negara yang tergabung dalam Uni Eropa. peta kendali EWMA dapat dilihat seperti Gambar 5.4 .1 berikut:
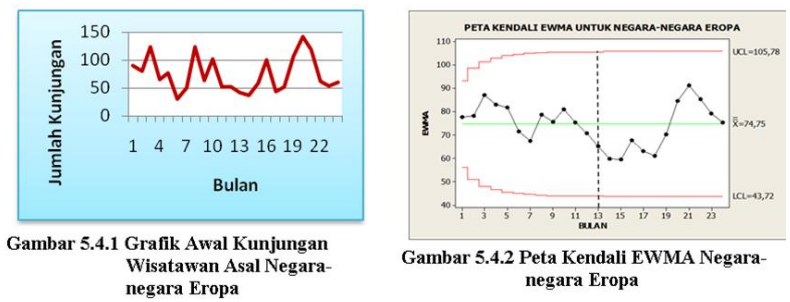

Dari peta kendali EWMA di atas terlihat bahwa seluruh nilai EWMA untuk kunjungan wisatawan asal negara-negara Eropa berada dalam batas kendali namun memiliki pola yang tidak acak. Pola yang dibentuk tersebut adalah pola. Puncak pada tahun 2014 lebih tinggi dibandingkan tahun 2013. Ini berarti jumlah kunjungan tertinggi pada tahun 2013 terjadi pada bulan Maret dan Oktober sedangkan pada tahun 2014 terjadi pada bulan September. Dan jumlah kunjungan terendah pada tahun 2013 terjadi pada bulan Juli dan bulan Juni pada tahun 2014. 


\subsection{Peta Kendali EWMA untuk Negara Amerika}

Warga negara Amerika tertarik berkunjung ke Indonesia karena Indonesia memiliki kekayaan alam yang kemudian dimanfaatkan menjadi tempat tujuan wisata. Inilah yang menarik wisatawan dari Amerika untuk berlibur ke Indonesia, termasuk juga ke Sumatera Barat. Pola kunjungan wisatawan asal Amerika dan peta kendali EWMA terlihat seperti Gambar 5.5.1 dan 5.5.2 berikut:

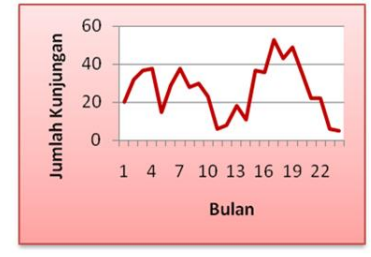

Gambar 5.5.1 Grafik Awal Kunjungan Wisatawan Asal Amerika

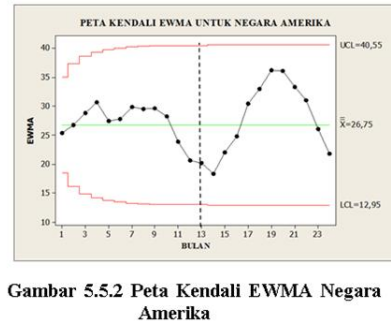

Amerika

Dari peta kendali EWMA di atas terlihat bahwa pola sudah mengalami pemulusan, terlihat dengan titik-titik ekstrim (variasi data) pada data awal yang sudah dapat dihilangkan. Seluruh nilai EWMA dari kunjungan wisatawan asal Amerika ini berada dalam batas kendali, namun memiliki pola yang tidak acak. Pada tahun 2013 pola naik terjadi pada bulan April, Juli dan Agustus sedangkan pada tahun 2014 hanya terjadi pada bulan Juli dan Agustus. Dan pola turun sama terjadinya untuk kedua tahun ini, yakni pada bulan Februari dan Desember. Sehingga dapat dilihat bahwa jumlah kunjungan meningkat pada bulan Juli dan Agustus dan terjadi penurunan di bulan Februari dan Desember.

\subsection{Peta Kendali EWMA untuk Negara-negara Lainnya}

Negara lainnya maksudnya disini adalah gabungan dari negara-negara selain negaranegara di atas, diantaranya Jepang, Thailand, India, China, Hongkong, dan lainnya. Jumlah wisatawan dari negara-negara ini hanya beberapa orang dan tidak tiap bulan ada wisatawan dari negara tersebut yang datang berkunjung ke Sumatera Barat, sehingga digabungkan. Grafik kunjungan wisatawan yang berasal dari negara-negara lainnya dan peta kendali EWMA dapat dilihat seperti Gambar 5.6.1 dan 5.6 .2 berikut.

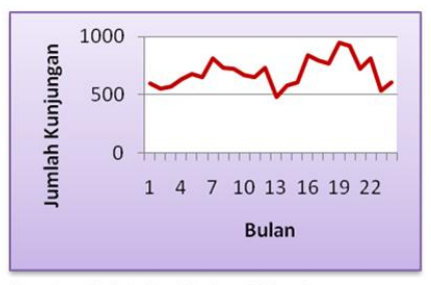

Gambar 5.6.1 Grafik Awal Kunjungan Wisatawan Asal Negaranegara Lainnya

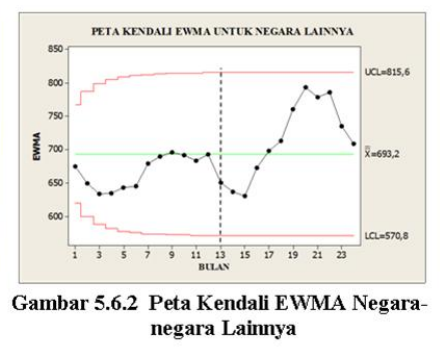

negara Lainnya 
Dari peta kendali EWMA di atas terlihat bahwa pola sudah mengalami pemulusan, yakni titik-titik ekstrim (variasi data) pada data awal sudah dapat dihilangkan. Seluruh nilai EWMA negara-negara lainnya ini berada dalam batas kendali, namun memiliki pola yang tidak acak. Terlihat dari gambar adanya pola yang berulang dari peta kendali EWMA untuk jumlah kunjungan wisatawan dari negara-negara lainnya pada kedua tahun tersebut. Pola naik/mencapai puncaknnya terjadi pada bulan Agustus sedangkan pola turun terjadi pada bulan Maret. Sehingga jumlah kunjungan meningkat pada bulan Agustus dan terjadi penurunan pada bulan Maret.

\section{Kesimpulan}

Berdasarkan hasil dan pembahasan dalam penelitian ini, dapat disimpulkan dari lima negara dan satu negara gabungan jumlah wisatawan dari berbagai negara yang berkunjung ke Sumatera Barat memiliki pola yang tidak acak, namun berada dalam batas kendali kecuali untuk negara Singapura. Negara Malaysia memiliki jumlah kunjungan yang tinggi dibandingkan negara-negara lainnya.

Berdasarkan peta kendali Exponentially Weighted Moving Average (EWMA), terlihat bahwa negara Malaysia memiliki jumlah kunjungan tertinggi pada bulan Desember dan kunjungan terendah terjadi pada bulan September. Australia, negara-negara Eropa, Amerika dan negara lainnya juga memiliki pola yang hampir sama dengan negara Malaysia. Sedangkan negara Singapura memiliki pola yang berbeda dari negara-negara lainnya, yakni polanya cenderung turun terus menerus bahkan pada bulan Maret dan April tahun 2013 data berada di luar batas kendali.

\section{Ucapan Terima kasih}

Penulis mengucapakan terima kasih kepada Ibu Riri Lestari, M.Si, Ibu Dr. Ferra Yanuar, dan Ibu Izzati Rahmi HG, M. Si yang telah memberikan masukan dan saran sehingga paper ini dapai diselesaikan.

\section{Daftar Pustaka}

[1] Montgomery, D, C. 2009. Introduction to Statistical Quality Control. Sixth Edition. Jhon Wiley and Sons, Inc, New York.

[2] Trietsch, D. 1999. Statistical Quality Control. MSIS Deapartment University of Auckland, New Zealand.

[3] Montgomery, D, C. 1998. Pengantar Pengendalian Kualitas Statistik. Jogyakarta: Gadjah Mada University Press.

[4] Firdaus, M. 2006. Analisis Deret Waktu Satu Ragam. IPB Press, Bogor.

[5] Oaklan, J S. 2003. Statistical Process Control. Fifth Edition. MPG Books Limited, Great Britian.

[6] Http://tempo.co/read/news/2014/03/06/Pariwisata-Indonesia-LampauiPertumbuhan-Ekonomi.html. Tanggal akses : 10 Agustus 2015.

[7] BPS. 2014. Perkembangan Pariwisata dan Transportasi Sumatera Barat. BPS Sumatera Barat. 